\title{
"Jeg er en transparent kiste" \\ - Yoko Tawadas produktive brug af kønsfilosofisk tankegods
}

Yoko Tawada er især kendt for skiftevis at skrive på tysk og japansk. Denne tosprogede skriftpraksis medfører et kontinuerligt fokus på selve sproget og ikke mindst på oversettelsen som fænomen. Og da Tawadas produktion er både litterær og litteraturteoretisk, opstår der i hendes forfatterskab en særegen synergi mellem teori og praksis. Tawadas forestilling om sproget synes især at være inspireret af dén tyske filosofi, som hun i sit videnskabelige arbejde har beskæftiget sig med, men i hendes litterare værker kan man indimellem spore helt andre teoretiske positioner, end de der eksplicit diskuteres $\mathrm{i}$ hendes essays og akademiske forelæsninger.

Følgende analyse af fortællingen Badet (Das Bad 1989/The Bath 2002)1 fokuserer på gennemgående tekstlige motiver, som synes at henvise til nogle af den (med teksten) samtidige kønsfilosofis kæpheste. Når Tawada skaber forbindelser mellem modermælken og den skriftlige praksis, foregår 
det uden tvivl med den berømte ecriture feminine som bevidst bagrund. Og når hendes fortæller faktisk transformerer sig til en transparent kiste, synes det at være en radikal udgave af den metaforisering af kvinden som ren og skær beholder (for manden og fostret), som ifølge blandt andre franske Luce Irigaray kan spores op gennem hele den vestlige metafysisk. Tawadas omgang med den kønsfilosofiske retorik er rent forbrugende: Badet er ikke et indlæg i en kønsteoretisk diskussion, og det er derfor ikke på nogen måde frugtbart at forsøge at uddrage en egentlig kønspolitisk holdning af fortællingen. Analysen kan derimod påvise, hvordan visse (berømte og berygtede) kønsfilosofiske koncepter har forplantet sig til litteraturen, hvor de hos f.eks. Tawada indgår som værdifulde bidrag til en stadig udforskning (og udfordring!) af kategorier som køn, sprog og nationalitet.

\section{"JEG ER EN TRANSPARENT KISTE" - FORTÆLLERENS GRADVISE TRANSFORMATION}

Badet (1989) er centreret om en unavngiven japansk kvinde, som fortæller i jegform, uden at hendes position som egentlig fortaller etableres: Det bliver aldrig klart, hoorfra hun taler, hvilket er en bemærkelsesværdig detalje, eftersom der er tale om en beretning om (og af) en kvinde, der dels făr sværere og sværere ved at kommunikere både verbalt og skriftligt, og dels har svært ved at fastholde en klar betydning af det $j e g$, som hun fortæller om. Selve teksten, som (på trods af sit mere og mere associativt strukturerede plot) i høj grad er veltalende, bliver således mere og mere selvmodsigende som dette efterhånden totalt opløste jegs udsigelse.

Fortælleren, der er tolk, lever så at sige af at lade andre mennesker kommunikere ved hjælp af sin tunge. Denne metafor for det at tolke forvandler sig i løbet af fortællingen til en faktisk fysisk realitet, efterhånden som fortællerens krop undergår en ret vidt- rækkende transformation. Det hele begynder med, at hun en morgen konstaterer, at hendes krop er dækket af skæl. Hendes pragmatiske reaktion på denne noget usædvanlige metamorfose er eksemplarisk for hendes tilgang til den forvandling, hun i løbet af fortællingen kommer til at lægge krop til:

Da jeg knappede min pyjamastop op, så jeg, at skællene dækkede ikke bare mit ansigt, men også mit bryst og mine arme. Hvis jeg begyndte at fjerne dem en for en, ville jeg komme for sent på arbejde. Jeg besluttede at tage et bad for at blødgøre skællene og derefter skrubbe dem af (Tawada 1989: 4).

Fra sin egen skællede krop associerer fortælleren til en lille historie om en sulten, gravid kvinde, som spiser en rå fisk uden at dele den med resten af den sultende landsby. Efter at have født en velskabt søn begynder kvinden at gro skæl og ender som en gigantisk fisk. Sønnen forsøger senere at frelse hende ved at gøre en ende på landsbyens sult og fattigdom: Han regner ud, hvor den omgivende bjergkæde må brydes for at gøre markerne fertile og får moderen til at kaste sin krop mod bjerget, indtil det giver efter. Moderens skæl løsner sig og hvirvler rundt i luften som blodige kirsebærblomster, og da bjerget til sidst falder, er hun sluppet af med skællene, men ender med at bløde ihjel i sin genvundne menneskeskikkelse.

Denne legendariske sammentænkning af fisken og den opofrende moderkrop tilbydes altså allerede fra fortællingens åbning som tolkningsramme for tekstens omfattende fiskemetaforik, og fungerer derfor også som klangbund, når fortælleren, der viser sig at være simultantolk, et par sider senere fortæller, at hun - primært på grund af navnet - altid bestiller sotunge, når hun er ude $\mathrm{i}$ embedsmedfør: "Når jeg spiser søtunge, mangler jeg aldrig ord at oversætte med" (Tawada 1989: 14). Indtagelsen af søtungen bliver altså en art garant for sproget. 
Måske især for det japanske modersmål, som fortælleren har et noget anstrengt forhold til: "Jeg er ikke særlig velegnet som tolk. Jeg hader mere end noget andet at tale, især mit modersmål" (Tawada 1989: 16).

Den dag fortælleren vågner med fiskeskæl, får hun imidlertid ikke mulighed for at bestille søtunge og făr (derfor?) sværere og sværere ved at udfylde sin rolle under et tysk/japansk forretningsmøde. Hun ender med at kollapse og kommer til sig selv i hænderne på, hvad der synes at være, en ansat på det hotel, hvor mødet finder sted. Inden hun helt kommer til bevidsthed, opnår fortælleren imidlertid det ønskede møde mellem sin egen tunge og søtungen, dog i en noget forskudt eller forvrænget form: Søtungen trænger ind i hendes mund, leger lidt med hendes tunge og ender med at fortære den. Hun er fra da af stum og følger tavst med kvinden fra hotellet.

I kvindens kolde, mørke kælderlejlighed bydes fortælleren på vin og brød, og da kvinden selv ingenting indtager, bliver nadver-parallellen hurtigt iøjnefaldende: Vinen har samme farve som blod, og brødet viser sig at være tørt som $k u l$, hvilket gør det til en passende metafor for - ikke Jesu legeme, men - kvindens egen krop, eftersom halvdelen af hendes ansigt er drkket af et brandsår. Dødsassociationerne bliver mere og mere gennemtrængende, og det hele kulminerer i et håndfast forførelsesforsøg:

"Det er ikke sandt, at man ikke behøver lide mere, når man er død. De døde længes endnu mere efter menneskelig kontakt, end de gjorde, mens de var i live.” Hun førte sin hånd ind under tæppet og placerede den på mit bryst. Min krop forstenede sig. "Luk nu dine øjne" sagde hun. Jeg lukkede mine øjne og så en ørken. Det føltes, som om jeg var bundet fast og ikke kunne bevæge mig. "Stik din tunge ud. Lad mig slikke den" (Tawada 1989: 15).

Da fortælleren efter en tid får revet sig ud af det forstenende favntag, viser det sig, at den døde kvinde er i besiddelse af hendes tunge.

Fra da af er fortællerens krop invaderet: Hun ser ikke sig selv men den døde kvinde, når hun kigger sig i spejlet, og hendes morgenrutine, som førhen bestod $\mathrm{i}$ at sminke sig til en lighed med et bestemt foto af sig selv, erstattes af forsøget på at male sig gennemsigtig, så den døde kvinde inden $\mathrm{i}$ hende bliver synlig. Og selvom hun selv er stum, forsøger hun at give kvinden stemme: "Man kunne sige, at jeg sammen med min tunge havde givet kvinden mit liv. Hver aften lyttede jeg til hendes stemme og skrev hendes ord ned" (Tawada 1989: 48). Ved tekstens slutning lever fortælleren et liv som mimer døden: Hun tilbringer stort set hele døgnet i sengen og invaderes hver aften af den døde kvinde, "Hver aften besøger kvinden denne verden gennem min hud" (Tawada 1989: 54). Denne gradvise selvudslettelse fuldendes i tekstens sidste linjer, hvor det jeg, som fortælleren refererer til, omsider er fuldstændigt blottet for både overflade og indhold:

Siden jeg ikke har nogen tunge, kan jeg ikke være tolk og oversætte, hvad kvinden siger til ord, der let kan blive forstået. Siden jeg har glemt alfabetets bogstaver kan jeg heller ikke længere være skribent. (...) Og selvfølgelig kan jeg mindst af alt være model, eftersom jeg på fotografier er komplet usynlig. Jeg er en transparent kiste (Tawada 1989: 55).

En af tekstens virkelig særegne kvaliteter er fortællerens manglende modvilje mod denne totale selvudslettelse - indimellem synes der næsten at være en vis eufori forbundet med det at miste sig selv. Måske fordi det selv, der i Badet forsvinder, i forvejen er en konstruktion, som fortælleren ikke nødvendigvis føler sig identisk med: Tekstens korte beskrivelser af relationen til kæresten Xander tegner således et næsten karikeret billede af kvinden som materiale, og manden som skaber. 
"MÆND ER LAVET AF TRÆ, KVINDER AF SILKE"

\section{- KVINDEN SOM MANDENS SKABNING}

Xander introduceres i teksten som ophavsmand til det foto, der hænger ved siden af spejlet og fungerer som facitliste for fortællerens ansigt. Af beskrivelsen af fotoets tilblivelse fremgår det, at det ansigt, som fotoet foreviger, er omhyggeligt konstrueret efter Xanders forestilling om den japanske kvinde: Fortællerens træk forstærkes eller overdrives forud for fotograferingen: Hendes i forvejen sorte hår farves sort, og hendes læber males med en stift af samme farve som disse. Xander er imidlertid ikke bare skaberen af fortællerens ansigt, men også af hendes sprog: Han fungerer som hendes sproglærer fra hun (adskillige år forud for fortællingens begivenheder) ankommer til Tyskland, uden at kunne et ord tysk. I undervisningen undgås oversættelsen af princip: frem for at forklare det tyske sprog gennem et andet, peger Xander på verden og benævner dens genstande. For fortælleren fungerer han altså som en egentlig navngiver med magt over de ord, som hendes tunge former:

"Dette er en bog." Det var det første Xander nogensinde sagde til mig. Jeg gentog sxtningen uden at vide, hvor et ord endte og det næste begyndte. "Dette er en bog." Da vi havde bevæget os videre til kuglepen og askebæger, var jeg allerede forelsket i Xander. Sådan føltes det i det mindste. Jeg kan på stedet forelske mig i én der lærer mig ord. Mens jeg gentog Xanders ord følte jeg, at min tunge begyndte at tilhøre ham (Tawada 1989: 27).

Xander behøver altså ikke fysisk at hive fortællerens tunge ud for at tage denne i sin besiddelse. Hun synes at afgive den frivilligt, efterhånden som modersmålet overlejres af fremmedsproget. Da undervisningen bevæger sig fra repetitionen af enkelte ord til kommunikation baseret på grammatiske regler, går det mindre godt. Fortælleren har store problemer med pronominer og den forskel, de indstifter, mellem dig og mig: "Når jeg blev spurgt, "Er du japansk?" ville jeg svare, "Ja, du er japansk" " (Tawada 1989: 28). For at overkomme pronomenproblemet anskaffer parret sig et sæt stedfortrædende dukker: Xander køber fortælleren en japansk dukke af silke, og fortælleren køber ham en blond violinist-marionet:

"Vil Xander få mulighed for at møde sin hjertenskær i morgen?" ville violinisten spørge, og silkedukken ville svare, "Sikkert ikke. Hun har ikke lyst til at mødes.” (...) Snart lærte jeg at forstå første- og andenperson, men Xander og jeg fastholdt tredjepersons-overenskomsten (Tawada 1989: 28).

Da fortælleren kommer hjem efter det første møde med den døde kvinde antydes det, at det ikke kun er pronomenproblemet, der håndteres ved de stedfortræedende dukker:

Med behændige fingre skrællede violinisten tøjet af silkedukken. (...) Da det sidste lag var borte, var kun dukkens hoved tilbage, eftersom hendes krop alene bestod af hendes tøj. Herefter tog violinisten sin smokingjakke, sin hvide skjorte og sine bukser af. Han havde intet kønsorgan, kun to skrøbelige ben (Tawada 1989: 29).

Da fortælleren ved en enkelt lejlighed foreslår at forsyne dukken med et organ af enten stof eller træ, bliver Xander irriteret og insisterer på, at der, selv uden den slags, er rigeligt med forskelle på mænd og kvinder:

"Mænd bevæges ovenfra ved hjælp af snore, mens kvinder bevæges direkte bagfra. Mænd er lavet af træ, kvinder af silke. Mænd kan lukke deres øjne, kvinder ikke. Disse forskelle er tilstrækkelige til at producere kærlighed" (Tawada 1989: 29).

Xander udleder altså selve definitionen af mand og kvinde fra de partikulære dukkers 
specifikke beskaffenheder. Han bekender sig til en i princippet essentialistisk opfattelse af kønsforskellen, det vil sige: til overbevisningen om kønnet som et naturgivent, biologisk vilkår, der ikke som sådant er til forhandling. Det paradoksale er, at han ligesom essentialismens modsætning, konstruktivismen, lokaliserer denne givne forskel i de ydre kønsmarkører. Hvilket for konstruktivismen er første skridt på vejen til at definere kønsforskellen som en kulturel konstruktion. For Xander handler det derimod om at få en partikulær repræsentation af manden og kvinden ophævet til facitliste for mand- og kvindekønnet. Dukkespillet bliver altså for fortælleren ikke blot et lærestykke i tysk grammatik, men en egentlig identitetskonstruktion baseret på et 'jeg' over for et 'du' og en 'mand' over for en 'kvinde'.

\section{DEN TRANPARENTE KISTE - KVINDEN SOM LIVMODER?}

Fortælleren, som hun fremstår ved fortællingens begyndelse, er altså i udstrakt grad Xanders skabning. Det er i denne forbindelse interessant, at Xanders sidste 'erhverv' er tømrer: Da 'manden' som bekendt er lavet af træ, bliver den mandlige tømrer en skaber, der skaber i sit eget billede, hvilket gør dette at skabe $i$ sit eget billede til fællesnævneren for alle Xanders virker, uanset om han fotograferer, underviser i sprog eller bygger møbler.

Betragtet under en kønsteoretisk optik er der imidlertid én interessant detalje, som afgørende adskiller Xanders kønskonstruktioner fra de tankeforestillinger om manden og kvinden, som ifølge feministisk kønsfilosofi har domineret vestlig metafysik: Hans tale om kønnene konkluderer, at de nævnte forskelle er nok til at producere karlighed. Som påvist af teoretikere som franske Luce Irigaray konceptualiseres relationen mellem mand og kvinde ganske ofte som en produktionsrelation - hvad der produceres er imidlertid ikke kærlighed men afkom. For
Irigaray er den heraf følgende identifikation af kvinden med moderen en af patriarkatets mest ulyksalige tankefigurer. Hun påviser, hvordan den patriarkalske grundmetafor for moderkroppen er linmoderen, der for den mandlige imaginære bevidsthed er på en gang rædselsvækkende og nærmest magnetisk: Irigaray fremhæver således i sine læsninger af for eksempel Platon og Spinoza figurer som bulen og omslaget som typiske metaforer for stedet, der i begge tilfælde peger tilbage på livmoderen som menneskets første nødvendige sted. ${ }^{2}$ Pointen er, at filosofiens relation til dette første sted primært er præget af begæret efter kontrol: Selve den filosofiske tænknings behov for at etablere et fundament af sikker viden og dens næsten tvangsmæssige spekulationer over kategorier som stedets sted og àrsagernes àrsag bliver under livmodermetaforens optik analog med det lille barns spekulation over sin egen oprindelse og kan altså anskues som et forsøg på i det mindste tankemæssigt at underlægge sig sit eget ophav.

Når fortælleren i Badet ender som en transparent kiste, mimer hun altså en klassisk konceptualisering af kvinden som beholder. Endog i en radikaliseret version, hvor gennemsigtigheden gør det svært at skelne mellem ydre og indre: Der er tilsyneladende ikke andet end hulrummet tilbage. Det er dog interessant, at hulrummet udfyldes ikke af en mandlig penetration eller et foster - men af en anden kvinde. En meningsfuld udlægning af denne anden kvinde kan imidlertid først finde sted hinsides analysen af dén kvinde, der måske i denne sammenhæng kan få betegnelsen den forste kvinde, nemlig fortællerens mor.

\section{DET MØDRENE HAV OG KVINDER MED SKÆL}

Det første fortælleren fortæller om sin mor er, at det er moderen, der har foræret hende det spejl, hvis reflektion hun hver morgen korrigerer med Xanders foto som model. Det skællede ansigt, som hun ved for- 
tællingens begyndelse ser i spejlet, viser sig senere at være lig det ansigt, som hun en måned tidligere er blevet konfronteret med under et besøg hos moderen i Japan: "Min mors ansigt var dækket af glinsende skæl" (Tawada 2002: 42). I løbet af det korte besøg gennemspiller de to kvinder hele repertoiret af klassiske mor-barn-konflikter: Moderen bebrejder datteren, at hun har forladt hende, og ikke mindst, at hun har forandret sig af mødet med en fremmed verden. Datteren insisterer mere og mere vedholdende på, at hun ikke kommer tilbage, og at selv hvis hun gjorde, ville hun stadig være en anden. Da moderen midt i det hele sætter sig op på sin kondicykel og går i gang med det daglige træningsprogram, som skal forhindre alderen $\mathrm{i}$ at indhente hende, oplever fortælleren at blive suget ind i pedalernes rytme og giver sig til at snurre rundt, mens hun synes at blive yngre og yngre:

Mine knæ blev bløde, mine hæle blev bløde. Jeg kunne ikke længere stå oprejst. Mine læber og mit anus brændte. Jeg græd som et spædbarn, skrigene fra et døende barn, der bliver suget ind i dets moders vagina. Hylende forsvandt jeg ind i hvirvelvindens mørke hul. Med min sidste styrke forbandede jeg min moder: "Død over kvinderne med skæl!" Pludselig var min krop dækket af skæl og jeg faldt ind i min egen vagina, hvirvelvindens mørke hul (Tawada 1989: 47).

Moderkroppens indre bliver her stedet for den ultimative udslettelse: Det mørke hul repræsenterer ikke døden, men en art annullering af livet. Tilføjelsen af de to sidste linjer, hvor fortælleren efter forbandelsen af moderen suges ind i sig selv, kan heroverfor ses som en fantasi om helt at undslippe moderskødet som menneskelig eksistensbetingelse til fordel for en totalt selvberoende eksistens.

De 'kvinder med fiskeskæl' - som fortælleren her fordømmer for kort efter selv at blive en af - udgør absolut et af tekstens egne mørkeste huller: Legenden i begyn- delsen af teksten synes at antyde en forbindelse mellem selve moderskabet og fisken. Men en egentlig oversættelse af 'skællet kvinde' til 'moder' virker ikke synderligt opklarende eller meningsproducerende for de af tekstens fiskeskælsscener, som optræder mod slutningen af fortællingen, hvor tekstsammenhængen bliver mere og mere skrøbelig og metaforerne stadigt mere produktive. For eksempel, når fortælleren (i hvad der måske blot er en drøm) bliver ansat som skællet dame i et cirkus. Hun skal her erstatte en afdød havfrue, og kontrasten mellem fortællerens fisketræk og den klassiske havfruefigur genkalder en interessant japansk gendigtning af Den lille havfrue, nemlig Kurahashi Yumikos Havfruens tàrer, hvor havfruen er fisk fra navlen og opad og dermed pludselig er seksuelt tilgængelig, men xstetisk ugangbar - stik modsat den ortodokse havfrue. Tawadas skællede fortæller synes ved første øjekast at være en tilsvarende upassende erstatning for cirkussets havfrue, men dennes dødsårsag (brystkræft) skaber en måske afgørende forbindelse mellem hende og fortælleren, som jeg i essayets sidste afsnit vil vende tilbage til. ${ }^{3}$

Fortælleren havner i cirkussets freakshow bestående af smukke kvinder, hvis 'optræden’ består i at slå hinanden bevidstløse og iføre de faldne brudekjoler. Ved det afsluttende massebryllup finder fortælleren sig selv liggende på et stort fiskefad: "En af brudene rejste sig, hævede sit glas og annoncerede, "Fra nu af vil vi leve hæderlige liv!" "Hæderlige liv!" ekkoede de andre kvinder. "Hvis noget stinker, vil vi sige at det stinker! Skællede mennesker stinker!" (Tawada 2002: 40). Herefter bliver fortælleren nærmest rituelt afskællet ligesom den fisk, hun selv ved fortællingens begyndelse indtog, da hun var ude som tolk. Det er her værd at bemærke, at brudenes fordømmelse går på mennesker med skæl, ikke kvinder med skæl og altså udgør en racistisk (eller i hvert fald 'artsbetinget') afstandtagen. ${ }^{4}$ Den historie, som fortælleren ved 
tekstens begyndelse fortæller i ly af mytens almene ramme, handler derfor måske slet ikke om den opofrende moder i al almindelighed, men om fortællerens egen mor. Fiskeskællene, som i øvrigt metaforiseres ved kirsebærblomsterne, selve grundsymbolet på japansk æstetik, kan under denne optik udlægges som et specifikt asiatisk træk, som altså bliver ved med at manifestere sig i fortællerens ansigt efter det urovækkende besøg hos moderen.

\section{MODERMÆLKEN SOM 'HVID BLÆK'}

Under fortællerens møde med moderen henvises imidlertid eksplicit til endnu en velkendt metafor for relationen mellem moder og barn, nemlig modermelken:

"Du fik stadig modermælk som femårig. Selv når vi havde gæster, bad du om mælk og græd. Jeg vidste ikke, hvad jeg skulle gøre.” Jeg havde ingen erindring om min moders bryst. Jeg overvejede, hvornår jeg sidst havde rørt hende. "Jeg talte med lægen og han grinede og sagde til dig: 'det er ikke hvad piger bør ville have’ og så - jeg ved ikke hvad du tænkte på - kastede du det keramiklegetøj, du stod med, i ansigtet på ham, så hårdt som du kunne. Du sårede ham, og han var så vred, at han bandede djevelsk og råbte: 'Jeg hiver din tunge ud!' (Tawada 1989: 45).

Lægen fungerer her som en næsten karikeret indstifter af en patriarkalsk orden, når han på én gang kontrollerer og begrænser adgangen til moderen, skitserer en lov for kønnenes begærsretninger ("Det er ikke hvad en pige bør ville have") og truer med at straffe oprøret mod loven med noget, der ligner en kastration. Det er imidlertid værd at bemærke, at hvor kastrationen i lacaniansk forstand er en apriori betingelse for selve adgangen til sproget (eller den symbolske orden), er det netop sproget, lægen truer med at tage. Når fortælleren senere faktisk får hevet tungen ud og mister ikke bare sin tale, men evnen til sproglig kommunikation i det hele taget, ligner det derfor en straf. Måske for fortællerens stadige indtagelse af varm mælk? Den kvinde, som ender med at tilegne sig fortællerens tunge, synes dog ikke at ville skride ind over for den slags lovovertrædelser. Især synes hun ikke at bekymre sig om, 'hvad piger bør ville have', men går som tidligere beskrevet direkte efter netop fortællerens bryst i det 'forførelsesforsøg', som finder sted i kælderlejligheden.

I en af fortællingens allermest fortættede og drømmeagtige sekvenser optræder modermælken igen og denne gang i en sammenhæng, hvor den forlenes med en ganske særlig kraft. Fortælleren, i hvis indre den døde kvinde kan skimtes, oplever sin seng forvandle sig til sarkofag i form af en skællet fugl, som senere viser sig at være den døde kvinde. Bemærk den hønen-ogxgget-agtige struktur, der gør det umuligt at gennemskue, hvem der egentlig fungerer som sted eller årsag for hvem. Fra den flyvende sarkofagfugl får fortælleren lejlighed til at betragte jorden fra oven og kan fra dette på alle måder forskudte perspektiv gøre sig nogle erkendelser, som for Tawadas værk udgør en helt central pointe:

Jeg spredte et verdenskort ud. På kortet er vandets bevægelse ophævet, så det ser ud som om alle byerne altid befinder sig på præcis samme sted. Utallige røde linjer, måske luftveje eller fiskenet, løber fra by til by. Jordens ansigt er fanget i dette net. Hver dag korrigerer mennesket dette ansigt ved at bruge kortet som model (Tawada 1989: 49).

Denne ansigtskorrektion er fuldstændig parallel med fortællerens egen morgenrutine - der som bekendt ophæves efter mødet med den døde kvinde. I begge tilfælde har noget, som egentlig blot er én partikulær representation, forvandlet sig til en facitliste for henholdsvis jeget og verden. Der er tale om stivnede representationer, som mennesket angiveligt er tilbøjeligt til at forveksle med virkeligheden i så udtalt grad, at 
denne må manipuleres, indtil den viser sit 'sande' ansigt.

Når linjerne, der forbinder og fikserer byerne, betegnes som fiskenet antydes det, at den 'virkelighed,' der skabes på baggrund af verdenskortet som repræsentation, er en virkelighed, hvor kvinden som fisk (det vil sige kvinden som moder) - og måske mennesker med skæl i det hele taget - bestandigt indfanges i de net, som mennesket udspænder for at opretholde forestillingen om dette partikulære verdenskort som sandheden om verden.

Fortællingen præsenterer imidlertid et alternativ til denne repræsentationsform. Et alternativ, der ligesom forestillingen om kvinden som transparent kiste, synes at være konstrueret med 'klassisk' kønsfilosofi som baggrund. Fortælleren overflyver i den flyvende sarkofag et krigsområde og spørges af en pludseligt ankommen spøgelsesstewardesse, om hun vil have kaffe eller te. Fortælleren vil - som den baby stewardessen bærer på - have mælk.

I dette øjeblik begynder mælk så hvid som papir at flyde ud af stewardessens kander, den slukker de krigsbrande, som har indhyllet planeten, blander sig med asken og trænger ned $\mathrm{i}$ jorden og forsvinder. Da alle brandene er slukket, er der ikke mere mælk tilbage (Tawada 1989: 50).

Den helende (moder)mælk er altså i stand til fjerne sporerne efter krigen, som netop må siges at være et udtalt symptom på menneskets tilbøjelighed til at (om)skabe verden (virkeligheden) med et bestemt verdenskort (en bestemt repræsentation eller verdensanskuelse) som facitliste. Den metaforiske forbindelse til papiret sidestiller denne mælkeudgydelse med de skriftlige repræsentationer, som den konkurerer med, og synes på dette punkt at være inspireret af den feministiske litteraturteoretiker Helene Cixous' utopi om en ecriture feminine. ${ }^{5}$ En skriftpraksis, der lanceres som et modstykke til en stivnet, målorienteret maskulin (eller fallisk) representationsform, som hævdes ikke at kunne rumme kvinden og kønsforskellen.

Denne skriftpraksis forbindes eksplicit med selve kvindekroppen, herunder med modermælken som ressource: Idealet bliver således hos Cixous, at skrive med såkaldt bvidt blak. Hos Tawada făr denne feministiske utopi et særegent poetisk udtryk i form af stewardessen (som i parentes bemærket ofte fungerer som en eksemplarisk, erotiseret kvindetype på linje med f.eks. sygeplejersken), der overskriver de ødelæggende, krigeriske diskurser med sin papirhvide mælk(eblæk).

\section{DEN TRANPARENTE KISTE SOM UTOPI OM AT RUMME SIG SELV OG SIT OPHAV} Efter denne nødvendige omvej over moderen og modermælken tør jeg igen nærme mig tekstens enigmatiske udgangsmetafor og spørgsmålet om udlægningen af den døde kvinde. Det er indledningsvist værd at bemærke, at selve døden som vilkår er usædvanlig præsent i fortællerens bevidsthed: Hun associerer spejlets rektangulære form med en kiste og reflekterer over det menneskelige skelet, der, mens kroppen er i live, ikke kan "holdes tæt". Og det faktum, at håret kan beskrives som dødt væv, får hende til at slutte direkte til sin egen dødelighed: "En del af min krop er allerede et lig” (Tawada 1989: 8). Der er altså en død kvinde i fortælleren fra begyndelsen. Og fortællingen synes på ét plan at handle om netop erkendelsen af ens egen evindelige transformation (fra foster til skellet) og om at få representationen af verden - i yderste forstand selve sproget - til at rumme denne erkendelse. Hvilket er præcis, hvad fortælleren hele tiden forsøger, hver gang pronominerne gør deres indtog, som i telefonsamtalen ved fortællingens begyndelse: "Det er dig?” Jeg tænkte over det et øjeblik og sagde, "Det er det ikke." "Hvis det ikke er dig, hvem er du så?"” (Tawada 1989: 5) Også barndommens stammende og for- 
vrængende omgang med det personlige pronomen watashi (jeg) er en variant af denne instinktive modvilje mod det at gøre sig identisk med en partikulær betegnelse. På japansk ledsages watashi af boku, som udelukkende benyttes af drenge og indebærer således en egentlig kategorisering af det talende subjekt. Den transformationsproces, som fortælleren undergår, kan udlægges som en radikalisering af dette oprør mod et jeg, som postulerer at henvise til en stabil og selvidentisk enhed: Jeget i "Jeg er en transparent kiste" henviser under denne optik ikke til fortælleren som person, men til selve det personlige pronomen og udgør en utopi om en rumlig sproglig 'beholder' for subjektet, som ikke forsyner dette med en ydre mærkat, en overflade, som 'indholdet' hele tiden skal tilpasses efter.

Den døde kvinde tilføjer immidlertid hele denne 'jeg-fortælling' endnu et lag. Med den døde kvinde som indhold bliver kisten nemlig samtidig til en utopi om selve det at fortalle som en proces, hvor det jeg, der taler, gør sig til krop og stemme (til beholder) for noget, som ikke kan fortælle sig selv. Badet er dette nogets fortælling. Teksten rummer således parallelt med refleksionerne over døden som alment vilkår, en konkret traumatisk erfaring, nemlig den krig der har sat dybe spor i både den japanske moder og den døde tyske kvinde. De krigsbrande som modermælken slukker, er på dette plan direkte forbundet med den døde kvindes brandsår.

Fortællingens titel (som for en umiddelbar betragtning forekommer lidt 'skæv') fremhæver netop dén korte passage fra seancen i kælderlejligheden, hvor dét, der ikke kan fortælles, gør opmærksom på sin tilstedeværelse. Den døde kvinde tager et koldt bad og forklarer: "Hvis ikke jeg gør det her, kan jeg ikke glemme de dårlige ting. I stedet for at skrige højt, fryser jeg skrigene og vasker dem af min hud" (Tawada 2009: 23). Denne sammentænkning af psykisk heling og 'hudpleje' har en parallel i fortællerens daglige påføring af lotion inde- holdende modermælk - en form for hudpleje, som angiveligt "beroliger nerverne." Den døde kvinde, som er født i krigens sidste år, har - som hun over for fortælleren pointerer - aldrig fået mælk, men fortællingen, som netop bærer navnet badet, er præcis det 'mælkebad', der (bedre end det kolde vand) kan pleje hendes sår.

Og måske er der faktisk tale om mere end én såret kvinde - den dødes ansigt forvandler sig nemlig under fortællerens blik:

Den højre side af kvindens ansigt var forvrænget af brandsår, som hærdet lava. Den venstre side havde et tankefuldt udtryk, som jeg syntes var smukt. Dette var umiskendeligt en fyrreårig kvindes skønhed, men hver gang jeg blinkede, så hun anderledes ud, nu som en lille pige og nu som en gammel kvinde (Tawada 2002: 19).

Der er dels tale om flere versioner af den samme kvinde, som bliver synlige på én gang, fordi fortælleren faktisk er i stand til at rumme hende $\mathrm{i}$ den flydende, ustabile form, som i følge teksten er jegets grundvilkår. Men under den anden optik, krigens optik, er der nærmere tale om flere forskellige kvinder (japanske såvel som tyske), som deler det samme sår. Det noget, som fortællingen giver stemme er altså snævert forbundet med fortællerens egen partikulære baggrund. Den transparente kistes utopi er således i yderste forstand utopien om at kunne rumme sin egen baggrund, sit eget ophav.

\section{DEN HVIDE BLÆKS POETIK}

Selve fortællingens form - de stadigt mere associativt forbundne scener, som insisterer på hele tiden at udtvære grænsen mellem hallucination og virkelighed - kan være lidt af en prøvelse for dens læser. Kæresten Xander ville, med sit essentialistisk orienterede repræsentationsideal, formentlig ikke bryde sig om den, hvilket faktisk antydes i teksten i form af hans indædte modvilje mod så 
meget som lugten af den mælk, som fortælleren kontinuerligt opvarmer: Mælken, den hvide blæk, er for poeter - ikke for fotografer, sproglærere og tømrere. Cirkussets afdøde havfrue bliver i denne sammenhæng igen interessant, for så vidt som hendes død synes at være udløst af, at hun bestandigt måtte lægge bryst (og mælk) til en ikke nærmere identificeret poet. Den post, som fortælleren (med eller uden skæl) overtager efter havfruen, er altså en post i poesiens tjeneste. Dog ikke som muse for en mandlig poet: Hvad fortælleren stiller sin tunge (og øvrige krop) til rådighed for, er selve fortællingen, selve teksten. Hun ender med som transparent kiste at legemliggøre et ideal om litteraturen som et sted, hvor jeg'et er til evig forhandling og hvor traumatiske erfaringer, som ikke kan kommunikeres, kan få krop og stemme. De tyske og japanske forretningsmænd brugte ved begyndelsen af teksten fortællerens tunge til blot at tale (hvilket fortælleren som bekendt hader). Med tungen deponeret hos den døde kvinde er hun ved tekstens slutning befriet fra denne kommunikative funktion og kan derfor - ligesom tekstens forfatter - sætte alt ind på at udvikle en alternativ og mere adækvat sproglig praksis.

\section{Noter}

1. Fortællingen, som er skrevet på japansk, befinder sig i den særegne situation kun at foreligge som oversættelse. Dem er der tilgengxld to af begge oversat fra den uudgivne japanske tekst. Jeg vil i det følgende gengive citater i oversættelse, som er blevet til på baggrund af begge oversættelser.

2. Se: Irigaray: Ethique de la différence sexuelle
3. Den tyske version anvender ikke ordet Meerjungfrau men Fischmench, hvilket er en direkte oversættelse af det japanske ord ningyo (menneskefisk), som i midlertid på japansk også bruges om havfrue, hvilket gengives på engelsk. Havfruen giver her mere mening, da det af teksten relativt fremgår, at der må være tale om en menneskelig (og specifikt kvindelig) overkrop.

4. Der er her igen tale en markant afvigelse i den tyske tekst, som anfører Schuppenträgerinnen. Selve betegnelsen 'skælbærer' ville imidertid ikke på japansk være kønnet. Og hvis der var tale om en anden specifik femininisering, ville den engelske oversættelse næppe vælge People with scales frem for Women with scales, det er derfor min fornemmelse, at feminiseringen er en tysk tilskrivelse. 5. Se "The Laugh of the Medusa"

\section{LITTERATUR}

. Cixous, Helene (1975/1976):”The Laugh of the Medusa", in Signs 1, 1975/76

- Irigaray, Luce (1984): Ethique de la différence sexuelle. Editions de Minuit, 1984

- Slaymaker, Doug (edt.) (2007): Yoko TawadaVoices from Everyphere. Lexington books, 2007.

- Tawada, Yoko (1989): Das Bad. Konkursbuchverlag, 1989.

- Tawada, Yoko (1993): Ein Gast. Konkursbuchverlag, 1993.

- Tawada, Yoko (1996): Gottoharuto-tetsudo. Kodansha, 1996.

- Tawada, Yoko (1996): Talisman. Konkursbuchverlag, 1996.

. Tawada, Yoko (2002):"The Bath", in Where Europe Begins. New Directions, 2002.

Christine Glensted

Cand.mag. i Litteraturvidenskab

Mombukagakusho Research Student

Waseda University

Tokyo 